\title{
Immunomodulating Actions of Nucleotides: Enhancement of Immunoglobulin Production by Human Cord Blood Lymphocytes
}

\author{
HARUMI JYONOUCHI, LEI ZIIANG-SHANBHAG, MICHAEL GEORGIEFF, AND \\ YOSHIFUMI TOMITA

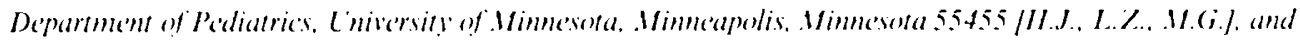 \\ Dipartme'ne of Animal Nutrition. Migazaki L'niversit!: Milazaki, Japan / Y.T.I
}

\begin{abstract}
ABSIRACI. We have shown previously that polynucleotides enhance in vitro antibody and $\mathrm{g}$ production in response to T-dependent antigens in mice and augment Ig production by adult human peripheral blood mononuclear cells. Herein, we report their effects on umbilical cord blood mononuclear cells (CBMINC) obtained from fullterm babies. CBNINC produced much less IgN//gG and an almost negligible amount of $\mathrm{Ig} A$ in response to various stimuli compared with adult peripheral blood mononuclear cells. The supplementation of yeast $R N A$ augmented spontaneous and T-dependent $\operatorname{IgM}(p<0.01)$ but not $\operatorname{lgG}$ production by $C B N I N C$. This action was largely attributable to polynucleotides, which appeared to exert their actions in a dose-dependent manner at the initial stages of culture. Their actions were dependent upon the presence of $\mathrm{T}$ cells, but they also enhanced spontaneous IgM production by CBIINC in the absence of 'T cells. Preincubation of $T$ cells from CBNINC and peripheral blood mononuclear cells with RNA for $3 \mathrm{~h}$ before the culture resulted in enhanced IgN production, independent of the stimulants used. Thus, polynucleotides appear to exert actions on immature human ' $\mathrm{T}$ cells as well as other lineage cells in vitro. Their actions may be dependent on the presence or absence of antigens or other stimuli and the nature of the stimuli ( $T$ dependent versus $T$ independent). These findings may further support the potential importance of nucleotides contained in human breast milk. (Pediatr Res 34: 565-571, 1993)
\end{abstract}

\section{Abbreviations}

CBMINC, cord blood mononuclear cell

PBNINC, peripheral blood mononuclear cell

PW'M, pokeweed mitogen

SAC, Staphylococcus aureus Cowan I

TD-Ag, T-dependent antigen

TNP-IPS, lipopolysaccharide modified with trinitrophenol

TNP-KI.H, keyhole limpet hemocyanin modified with trinitrophenol

FT, full-term

Ab, antibody

Ag, antigen

Con $A$, concanavalin $A$

S.I., stimulation index

Received November 25. 1992: accepted July 8, 1993

Correspondence and reprint requests: Harumi Jyonouchi. M.D.. Division of Immunology. Department of Pediatrics, University of Minnesota. Box 610 . UMHC. 420 Delaware St.. S.E.. Minneapolis. Minnesota 55455 .

Supported by grants from NIH (A12506.3). Minnesota Medical Foundation, Graduate In-Aid. University of Minnesota, and Viking Children's Fund (to 11.J.).
Neonates are born with a relatively underdeveloped immune system, and an exponential expansion and maturation of lymphoid organs occurs in early infancy. Lymphocytes, key components in the immune system, have a limited capacity for de nowo synthesis of nucleotides. When the human body grows rapidly. as in early infancy, lymphocytes may be dependent on dietary nucleotides to mature and function well. For this reason, the nucleotides contained in breast milk may be of physiologic importance. Nevertheless, the actions of nucleotides on lymphocyte functions are still not well understood. We have shown before that polynucleotides significantly enhance in vitro $\mathrm{Ab} / \mathrm{Ig}$ production in response to $\mathrm{TD}-\mathrm{Ag}$ but do not further facilitate polyclonal $B$ cell activation in experimental animal models ( 1 . 2). In humans, PBMNC from healthy adults produced more IgM and $\mathrm{IgG}$ in response to TNP-KLH, a TD-Ag, and PWM, which is a nonspecific $\mathrm{T}$-dependent stimulant (3). However, immature human lymphocytes appear to be poorly responsive to $\mathrm{T}$-dependent stimuli (4-7), which potentially undermines the significance of any enhancing action of RNA/polynucleotides on $\mathrm{Ab} /$ Ig production in carly infancy.

This study was thus formulated to examine the effects of yeast RNA preparations on immature human lymphocytes by using CBMNC from FT babies. We demonstrated that polynucleotides mainly enhance IgM production by CBMNC through exerting actions on both $\mathrm{T}$ and other lineage cells.

\section{MATERIALS AND METHODS}

Experimental Design. Experiments were conducted to study several subjects.

1) In vitro Ig production by CB.HAC' in response' to T-de'pende'nt and T-inde'pende'nt stimuli in presence' of RN.1 and monomuclentide mixture. These experiments were formulated to determine whether yeast RNA or a mononucleotide mixture patterned after those present in human breast milk could enhance in vitro Ig production by CBMNC in a dose-dependent manner.

2) liffects of chemically modificed/degraded RN.1 on in vitro Ig production by C $C B . M N C$. This study was designed to examine whether the immunomodulating actions of RNA on Ig production by CBMNC are attributable to polynucleotides or their degraded products.

3) Mechanisms of action of RN.1 on in vitro Ig production by $C B . M N C$. These experiments were formulated to determine the target cell population for the actions of RNA and to explore the mechanisms of the actions of RNA. We examined the following subjects: I) effects of time course of the addition of RNA to the culture, 2) effects of RNA on proliferation of T cells and other lineage cells, 3) effects of depletion of T cells from CBMNC on the actions of RNA, 4) effects of serum-free medium on the 
actions of RNA, and 5) effects of preincubation of unseparated, T-depleted, and T-enriched CBMNC with RNA before the culture.

CBMNC were obtained from FT newborns born in the delivery ward at the University of Minnesota Hospital. They were born to normal, healthy mothers, did not have any significant complications in their perinatal periods, and had appropriate weights for their ages. Seventy percent of the cord blood samples were obtained from babies born to Caucasian females, and the rest of the samples were obtained from babies born to black or Southeast Asian females. FT babies born to mothers with significant complications such as diabetes mellitus, toxemia, or infection at the time of delivery were excluded from this study. As controls, PBMNC from healthy adult volunteers were used. Typically one to two cord blood samples and one control sample were used in each experiment. The methodologies used in this study were as follows.

Preparation of Cell Suspensions. CBMNC were separated by Ficoll-Hypaque gradient and washed three times with PBS, $\mathrm{pH}$ 7.4. T cells were depleted from PBMNC by $\mathrm{E}$ rosetting with neuraminidase-treated sheep red blood cells after Ficoll-Hypaque gradient. T-cell-enriched cell suspensions were also used in some experiments after being placed in ice-cold $\mathrm{NH}_{4} \mathrm{Cl}(0.17 \mathrm{M})$ for 5 min to lyse sheep red blood cells and washed three times in PBS. More than $95 \%$ of the cells in the T-cell-enriched cell suspensions expressed pan T-cell markers (CD3 and CD5).

Ig Production Assay. PBMNC were incubated for 7 to $14 \mathrm{~d}$ in RPMI 1640 supplemented with 2\% FCS (Hyclone, Logan, UT). penicillin and streptomycin $(\mathrm{P}+\mathrm{S}), \mathrm{N}$-2-hydroxyethylpiperazine- $N^{\prime}$-2-ethanesulfonic acid, glutamine, and 2-mercaptoethanol $\left(10^{-6} \mathrm{M}\right)\left(10^{9}\right.$ cells $\left./ \mathrm{L}\right)$ in $5-\mathrm{mL}$ disposable plastic tubes (Costar, Cambridge, MA). In some experiments, FCS was replaced by a defined serum replacement product (TCM; $2 \%$, CELOX Corp., Hopkins, MN) to test the effects of a serum-free medium because FCS contains fair amounts of nucleosides and nucleic acids. Stimuli used to potentiate Ig production included SAC $(0.05 \mathrm{~g} / \mathrm{L})$ as a T-independent stimulant and PWM (1:1000) as a T-dependent stimulant. TNP-KLH $(10 \mathrm{mg} / \mathrm{L})$ and TNPLPS $(2 \mathrm{mg} / \mathrm{L})$ were used as TD-Ag and T-independent Ag, respectively (8). Concentrations of stimuli used were those with which the optimal actions of nucleotides were observed in both humans and animals (1-3). After the incubation of cells in a $5 \%$ $\mathrm{CO}_{2}$ incubator for 7 to 14 d at $37^{\circ} \mathrm{C}$, supernatants were harvested, $0.2 \mathrm{~g} / \mathrm{L} \mathrm{NaN}_{3}$ was added, and they were kept at $4^{\circ} \mathrm{C}$ until the time of use. IgG, IgM, and IgA levels in the harvested supernatant were measured by standard solid-phase ELISA assay (9). Namely, plates for the ELISA assay (F96 Maxisorp, Nunc, Naperville, IL) were coated with anti-human $\mathrm{Ig}(10 \mathrm{mg} / \mathrm{L})$ overnight at $4^{\circ} \mathrm{C}$ in $0.1 \mathrm{~N} \mathrm{NaHCO}_{3}$ coating buffer, pH 9.6 , with $0.2 \mathrm{~g} / \mathrm{L} \mathrm{NaN}_{3}$. After washing the plate with rinse buffer (PBS, pH 7.4, 0.05\% Tween $20)$, samples were diluted with dilution buffer $(0.05 \mathrm{M}$ Tris, $\mathrm{pH}$ 8.1, $\mathrm{MgCl}_{2} 1 \mathrm{mM}, \mathrm{NaCl} 0.15 \mathrm{M}, 0.05 \%$ Tween $20,0.2 \mathrm{~g} / \mathrm{L}$ $\mathrm{NaN}_{3}$, and $10 \mathrm{~g} / \mathrm{L} \mathrm{BSA}$ ) and incubated at room temperature for $2 \mathrm{~h}$. The plate was then washed with rinse buffer and incubated with a second $\mathrm{Ab}$ (Goat anti-human IgG-, IgM-, or IgA-alkaline phosphatase conjugate, $1: 1000$ to $1: 3000$ dilution, Sigma Chemical Co., St. Louis, MO). The color was developed by adding substrate solution (104 Phosphatase Substrate Tablet, 1 tablet/5 $\mathrm{mL}$, Sigma). OD at $410 \mathrm{~nm}$ was read by an ELISA reader. Monoclonal human IgG, IgA, and IgM (Sigma) were used as standards in each assay.

Limphocyte Proliferation Assay: Cells (PBMNC, CBMNC, Tenriched cell suspensions, and T-depleted cell suspensions) were incubated for $48 \mathrm{~h}$ in the presence of various stimuli $\left(10^{6}\right.$ cells/ $\mathrm{mL}$ ) in a 96-well flat-bottomed microtiter plate (Costar). Then $20 \mu \mathrm{L}$ of MTT [3-(4,5-dimethylthiazol-2-yl)-2,5-diphenyltetrazolium bromide, Sigma, $1.5 \mathrm{mg} / \mathrm{mL}$ in PBS] was added to each well (10). The plate was further incubated for $6 \mathrm{~h}$ in a $5 \% \mathrm{CO}_{2}$ incubator at $37^{\circ} \mathrm{C}$, and then $100 \mu \mathrm{L}$ of $10 \% \mathrm{SDS} / 50 \%$ buthanol were added to each well. OD was read by an ELISA reader at
$570 \mathrm{~nm}$ with a reference OD of $630 \mathrm{~nm}$. Con $\mathrm{A}(1 \mu \mathrm{g} / \mathrm{mL})$ was used as a positive control. Results were expressed as S.I. by dividing the value with that obtained in the absence of any stimuli.

Reagents. SAC (Pansorbin, Calbiochem. San Diego, CA), PWM (GIBCO-BRL, Gaithersburg. MD), and TNP-LPS (Sigma) were obtained from the commercial sources indicated. Keyhole limpet hemocyanin (Calbiochem) was modified with trinitrophenol in our laboratory as described elsewhere (8). Yeast RNA used in this study were used for the production of the commercially available formula (IMPACT) and kindly provided by Sandoz Nutrition Corp., Minneapolis, MN. The component of these RNA preparations had already been extensively analyzed by the company (RNA $91 \%$, hydrolyzate of RNA $5.0 \%$. cold acidsoluble fraction including sodium salts of mononucleotides $1.0 \%$, sugars $0.5 \%$, and $\mathrm{NaCl} 2.5 \%$ ). No significant endotoxin contamination was detected [Endotoxin contained was less than $1 \mathrm{ng} / \mathrm{L}$ in $10 \mathrm{~g} / \mathrm{L}$ RNA solution (Toxicolor system. Scikagaku Kogyo, Tokyo, Japan)]. Further addition of polymyxin B, a specific endotoxin inhibitor $(50 \mathrm{mg} / \mathrm{L})$, did not inhibit the actions of RNA on either PBMNC or CBMNC. The RNA preparations were kept at $-20^{\circ} \mathrm{C}$ in lyophilized form and dissolved into diethylpyrocarbonate-treated water on the day of the experiment. Food and Drug Administration-approved purificd nucleotide monophosphates (AMP, cytidine monophosphate, GMP, inosine monophosphate, and uridine monophosphate) that were used for the production of the infant formula (SMA) were kindly provided by Wyeth-Ayerst Research, Philadelphia, PA. A stock solution of a mononucleotide mixture was prepared (cytidine monophosphate $16.5 \mathrm{~g} / \mathrm{L}$. uridine monophosphate $5 \mathrm{~g} / \mathrm{L}$. AMP $4 \mathrm{~g} / \mathrm{L}$, GMP $2 \mathrm{~g} / \mathrm{L}$, and inosine monophosphate $2 \mathrm{~g} / \mathrm{L}$ in diethylpyrocarbonate-treated water). The stock solution was aliquoted and kept at $-20^{\circ} \mathrm{C}$ until the time of use. Typically, the mononucleotide mixture used in the experiments was either a $1: 1000$ or $1: 10000$ dilution of this mixture. A 1:100 dilution of this stock solution corresponds to the concentration of each nucleotide monophosphate contained in human breast milk.

Chemical Modification of $R N_{i}$. T The yeast RNA preparations were chemically modified as follows: 1) RNA solution $(2 \mathrm{~g} / \mathrm{L})$ was dialyzed and lyophilized without any other treatment (control); 2) cytosine bases of RNA were modified with $2 \mathrm{M} \mathrm{NH}_{2} \mathrm{OH}$. $\mathrm{HCl}, \mathrm{pH} 6.2$, for $5 \mathrm{~d}$ at $30^{\circ} \mathrm{C}$, which resulted in the formation of hydroxylaminated cytosine bases $(11) ; 3$ ) uridine bases of RNA solutions were modified with $2 \mathrm{M} \mathrm{NH} 2 \mathrm{OH} \cdot \mathrm{HCl}, \mathrm{pH} 9.0$, for $5 \mathrm{~d}$ at $30^{\circ} \mathrm{C}$, which resulted in the formation of ribose oxime derivatives via ribosyl urea (11); 4) RNA was decomposed by alkalinization (Korthoff buffer: $0.1 \mathrm{M} \mathrm{Na}_{2} \mathrm{CO}_{3}-0.1 \mathrm{M} \mathrm{HCl}, \mathrm{pH} \mathrm{11.0)}$ for $20 \mathrm{~min}$ at $70^{\circ} \mathrm{C}$, which resulted in $10 \%$ breakage of phosphodiester bonds in RNA (12); 5) RNA was decomposed with Korthoff buffer for $2 \mathrm{~h}$ at $70^{\circ} \mathrm{C}$, which resulted in $50 \%$ breakage of phosphodiester bonds in RNA (12); and 6) RNA was oxidized with $\mathrm{KMnO}_{4}(26.4 \mathrm{mM}, \mathrm{pH} 6.7)$ for $30 \mathrm{~min}$ at $0^{\circ}$, which was reported to cause decomposition of most pyrimidine bases in nucleotides and $20 \%$ of pyrimidine bases in transfer RNA (13). Then RNA samples were dialyzed against $0.05 \mathrm{M} \mathrm{NaCl}$ once, against sterile distilled water three times, and then lyophilized and kept at $-20^{\circ} \mathrm{C}$ until the time of use. During the period of dialysis, oligonucleotides smaller than $4 \mathrm{bp}$ were thought to be lost because the cutting molecular weight of dialyzing membrane used was 1000 .

\section{STATISTICS}

Statistical analyses were performed with the $t$ test or Welch's test based on the results of $F$ tests. $p<0.05$ was considered to be significant.

\section{RESULTS}

In Vitro Ig Production by CBMNC in Response to Various Stimuli. IgM, IgA, and IgG levels of the culture supernatant of 
CBMNC were measured when cells were stimulated by PWM, SAC, TNP-KLH, and TNP-LPS for $7 \mathrm{~d}$ in the presence of yeast RNA or the mononucleotide mixture. The results obtained in 12 FT babies and in 14 adult volunteers are summarized in Table 1. CBMNC were almost nonresponsive to PWM and TNP$\mathrm{KLH}$, both of which are T-dependent stimuli. CBMNC responded modestly to SAC and TNP-LPS for IgM production but not for IgG production. IgA production by CBMNC was virtually undetectable irrespective of the stimulus used. The supplementation of RNA $(0.1 \mathrm{~g} / \mathrm{L})$ appeared to enhance spontaneous IgM production by CBMNC. IgM production in response to PWM and TNP-KLH, both of which are T dependent, was also augmented by RNA to some extent (Table 1). These enhancing actions of RNA on IgM production by CBMNC appeared to be dose dependent (Fig. 1). However, IgM production in response to SAC or TNP-LPS was not significantly enhanced by RNA in either adults or newborns. IgG production by CBMNC in response to these stimuli was significantly less compared with that of PBMNC and was not appreciably altered in the presence of RNA. When cells were incubated for a longer period, adult PBMNC produced more IgG ( $>1000 \mathrm{ng} / \mathrm{mL}$ with PWM stimulation when incubated over $10 \mathrm{~d}$ ). However, $\operatorname{IgG}$ or $\operatorname{IgA}$ production by CBMNC was not further augmented by the longer incubation period (data not shown).

Effects of the mononucleotide mixture patterned after the mononucleotide content in human breast milk were also examined. Because RNA enhanced Ig production potentiated by PWM and TNP-KLH, we examined the effects of the mononucleotide mixture on Ig production potentiated by these stimulants. Supplementation with the mononucleotide mixture $\left(1: 10^{3}\right)$, the concentration of which may be close to that of mononucleotides in the gut of breast-fed infants, instead modestly suppressed Ig production (Table 1). A lower concentration of the mononucleotide mixture $\left(1: 10^{4}\right.$ and $1: 10^{5}$ of stock solution) did not alter Ig production by $C B M N C$ either. $A$ higher concentration of mononucleotides (1:100 to 1:500 of stock solution) even seemed to slightly suppress Ig production by CBMNC. IgM/IgG production by CBMNC in response to SAC and TNP-LPS was not altered in the presence of the mononucleotide mixture, as observed in the presence of whole RNA preparations in two experiments. No detectable $\operatorname{Ig} A$ was produced by CBMNC in the presence of the mononucleotide mixture (data not shown).

Effects of Chemically Modified RNA on Ig Production by. $P B M N C$. RNA samples were modified as detailed in Materials and Methods. These chemically modified RNA samples were studied for their actions on Ig production by CBMNC in the presence of medium alone or PWM $(1: 1000)$. Changes of IgM production in four experiments were summarized in Table 2. Neither IgG nor IgA production by CBMNC were altered signif-

Table 1. Changes of Ig production by. CBMNC in response to various stimuli with supplementation of RN.1*

\begin{tabular}{|c|c|c|c|}
\hline & \multicolumn{3}{|c|}{ Ig production by CBMNC in the presence of } \\
\hline & No reagent & $\begin{array}{c}\mathrm{RNA} \\
(0.1 \mathrm{~g} / \mathrm{L})\end{array}$ & $\begin{array}{l}\text { Mononucleotide } \\
\text { mixture } \dagger \\
(1: 1000)\end{array}$ \\
\hline \multicolumn{4}{|l|}{ IgM production } \\
\hline No stimulus & $\begin{array}{r}110 \pm 28.5 \\
(500 \pm 101)\end{array}$ & $\begin{array}{l}265 \pm 68.1(p<0.05) \\
(832 \pm 120)\end{array}$ & $\begin{array}{l}71.4 \pm 21.8 \\
(352 \pm 79.0)\end{array}$ \\
\hline PWM & $\begin{array}{r}169 \pm 37.5 \\
(1009 \pm 125)\end{array}$ & $\begin{aligned} 317 & \pm 68.2(p<0.01) \\
(1890 & \pm 122)\end{aligned}$ & $\begin{array}{l}84.9 \pm 23.7 \\
(787+157)\end{array}$ \\
\hline SAC & $\begin{array}{c}644 \pm 126 \\
(1093 \pm 212)\end{array}$ & $\begin{array}{c}880 \pm 126 \\
(1621 \pm 283)\end{array}$ & \\
\hline TNP-KLH & $\begin{array}{r}114 \pm 41.1 \\
(701 \pm 144)\end{array}$ & $\begin{aligned} 280 & \pm 57.1(p<0.05) \\
(1234 \pm 102) & \end{aligned}$ & $\begin{array}{c}76.1 \pm 26.7 \\
(686 \pm 95.1)\end{array}$ \\
\hline TNP-LPS & $\begin{aligned} 545 & \pm 100 \\
(1009 & \pm 157)\end{aligned}$ & $\begin{array}{r}623 \pm 111 \\
(1282 \pm 111)\end{array}$ & \\
\hline \multicolumn{4}{|c|}{ IgG production $(\mu \mathrm{g} / \mathrm{L})$} \\
\hline No stimulus & $\begin{array}{c}54.8 \pm 16.5 \\
(60.6 \pm 16.6)\end{array}$ & $\begin{array}{c}71.5 \pm 23.7 \\
(64.2 \pm 19.5)\end{array}$ & $\begin{array}{c}43.0 \pm 13.2 \\
(63.3 \pm 29.2)\end{array}$ \\
\hline PWM & $\begin{array}{l}57.9 \pm 15.0 \\
(171 \pm 30.7)\end{array}$ & $\begin{array}{l}55.5 \pm 14.7 \\
(310 \pm 37.1)\end{array}$ & $\begin{array}{c}38.4 \pm 17.3 \\
(86.8 \pm 18.9)\end{array}$ \\
\hline SAC & $\begin{array}{c}56.3 \pm 21.6 \\
(82.4 \pm 24.8)\end{array}$ & $\begin{array}{l}49.9 \pm 19.0 \\
(135 \pm 19.4)\end{array}$ & \\
\hline TNP-KLH & $\begin{array}{c}29.6 \pm 9.1 \\
(56.9 \pm 22.0)\end{array}$ & $\begin{array}{l}34.9 \pm 9.5 \\
(143 \pm 26.4)\end{array}$ & $\begin{array}{c}28.5 \pm 20.7 \\
(61.8 \pm 20.2)\end{array}$ \\
\hline TNP-LPS & $\begin{array}{c}52.6 \pm 8.1 \\
(53.1 \pm 16.0)\end{array}$ & $\begin{aligned} 47.4 & \pm 7.5 \\
(88.5 & \pm 25.0)\end{aligned}$ & \\
\hline \multicolumn{4}{|c|}{$\lg A$ production $(\mu \mathrm{g} / \mathrm{L})$} \\
\hline No stimulus & $\begin{array}{c}<6.25 \\
(127 \pm 25.8)\end{array}$ & $\begin{aligned} & <6.25 \\
(142 \pm 17.1) & \end{aligned}$ & \\
\hline PWM & $\begin{array}{c}<6.25 \\
(119 \pm 25.2)\end{array}$ & $\begin{aligned}<6.25 \\
(164 \pm 28.7)\end{aligned}$ & \\
\hline SAC & $\begin{array}{c}<6.25 \\
(148 \pm 33.3)\end{array}$ & $\begin{aligned} &<6.25 \\
&(192+33.4)\end{aligned}$ & \\
\hline TNP-KLH & $<6.25$ & $<6.25$ & \\
\hline TNP-LPS & $\begin{array}{c}(109 \pm 39.1) \\
<6.25 \\
(128 \pm 39.1)\end{array}$ & $\begin{aligned}(100 \pm & 31.0) \\
& <6.25 \\
(101 \pm & 30.9)\end{aligned}$ & \\
\hline
\end{tabular}

* These data were obtained from 12 CBMNC samples from FT babies ( $>37 \mathrm{wk}$ ). Control values of Ig production produced by PBMNC from 14 healthy adult volunteers are shown in parentheses. All Ig levels were expressed as mean \pm SEM. Concentrations of stimulants used to potentiate Ig production were as follows: PWM (1:1000), SAC $(0.05 \mathrm{~g} / \mathrm{L})$. TNP-KLH $(10 \mathrm{mg} / \mathrm{L})$, and TNP-LPS $(2 \mathrm{mg} / \mathrm{L})$.

$\dagger$ The effects of the mononucleotide mixture were tested on seven cord blood samples from FT babies. 


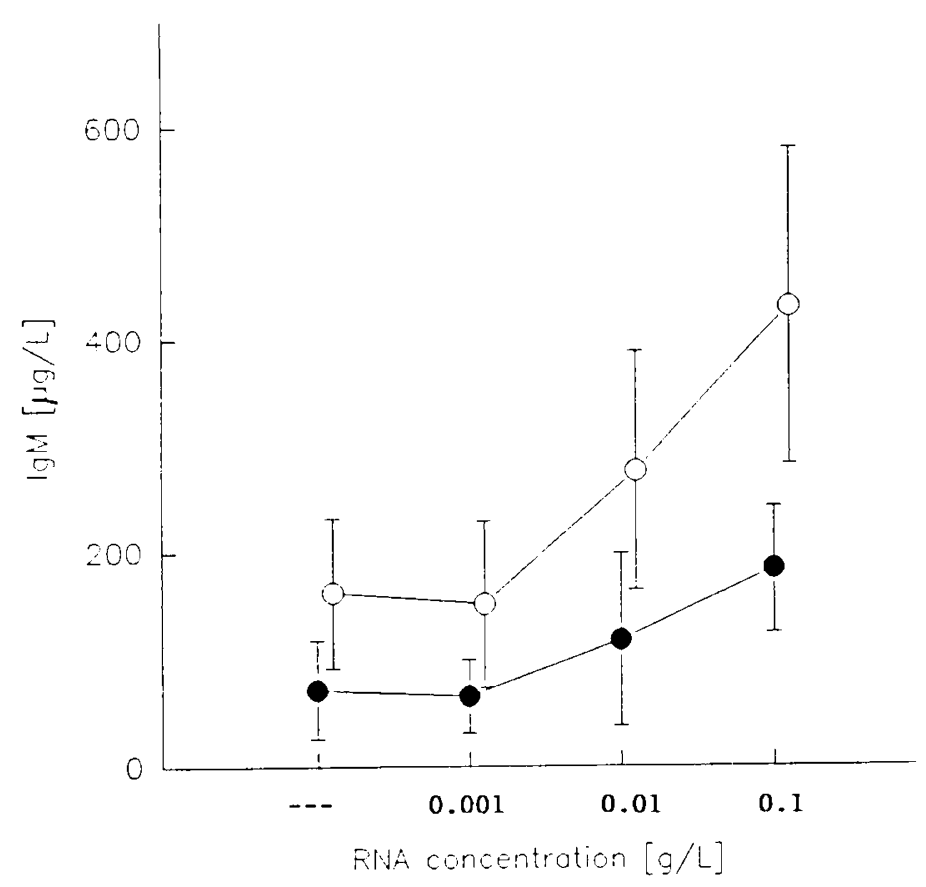

Fig. 1. IgM production by CBMNC in the presence of various amounts of yeast RNA preparations. Spontaneous (๑) and PWM (1:1000)-potentiated $(O)$ IgM production were examined. These are the results of four experiments. CBMNC were obtained from four different individuals.

Table 2. Changes of IgM production by CBMNC in presence of $R N A$ with various chemical modifications*

\begin{tabular}{|c|c|c|}
\hline & \multicolumn{2}{|c|}{$\begin{array}{l}\text { IgM production }(\mu \mathrm{g} / \mathrm{L}) \text { when } \\
\text { potentiated with }\end{array}$} \\
\hline & No stimulus & PWM (1:1000) \\
\hline No RNA & $77.1 \pm 29.7$ & $89.3 \pm 21.8$ \\
\hline RNA $(0.1 \mathrm{~g} / \mathrm{L})$ & $112 \pm 14.8$ & $184 \pm 28.7$ \\
\hline RNA $1(0.1 \mathrm{~g} / \mathrm{L})$ & & $157 \pm 35.6$ \\
\hline RNA $2(0.1 \mathrm{~g} / \mathrm{L})$ & & $83.9 \pm 19.2(p<0.05) \dagger$ \\
\hline RNA $3(0.1 \mathrm{~g} / \mathrm{L})$ & & $94.9 \pm 24.3(p<0.1)$ \\
\hline RNA $4(0.1 \mathrm{~g} / \mathrm{L})$ & & $127 \pm 24.8$ \\
\hline RNA $5(0.1 \mathrm{~g} / \mathrm{L})$ & & $87.8 \pm 37.0(p<0.1)$ \\
\hline RNA $6(0.1 \mathrm{~g} / \mathrm{L})$ & & $31.0 \pm 11.7(p<0.02)$ \\
\hline
\end{tabular}

* RNA samples were treated as follows: control RNA 1, dialyzed and lyophilized without any treatment: RNA 2 treated with $1 \mathrm{M} \mathrm{NH} \mathrm{N}_{2} \mathrm{OH}$. $\mathrm{HCl}, \mathrm{pH} 6.2$, for $5 \mathrm{~d}$ at $20^{\circ} \mathrm{C}$ to modify cytosine bases: RNA 3 treated with $2 \mathrm{M} \mathrm{NH}_{2} \mathrm{OH} \cdot \mathrm{HCl}, \mathrm{pH} 9.0$, for $5 \mathrm{~d}$ at $30^{\circ} \mathrm{C}$ to modify uridine bases; RNA 4 decomposed with alkaline (Korthoff buffer: $0.1 \mathrm{M} \mathrm{Na}_{2} \mathrm{CO}_{3}, \mathrm{pH}$ 11.0 ) for $20 \mathrm{~min}$ at $70^{\circ} \mathrm{C}$; RNA 5 decomposed with alkaline (Korthoff buffer) for $2 \mathrm{~h}$ at $70^{\circ} \mathrm{C}$; and RNA 6 oxidized with $24.6 \mathrm{mM} \mathrm{KMnO}_{4} 4$, pH 6.7 , for $30 \mathrm{~min}$ at $0^{\circ} \mathrm{C}$. Then all RNA samples were dialyzed, lyophilized. and $\mathrm{kept}$ at $-20^{\circ} \mathrm{C}$ until the time of use.

$+p$ values were obtained by comparing the $\operatorname{lgM}$ levels in each setting with those obtained in the presence of PWM and untreated RNA.

icantly in the presence of these modified RNA samples (data not shown). Modification of RNA samples resulted in loss of most of their enhancing actions on IgM production by CBMNC in response to PWM. This was especially evident when RNA samples were modified from cytosine or uridine bases, oxidized, or degraded with alkaline (Korthoff buffer, pH 11) for $2 \mathrm{~h}$ at $70^{\circ} \mathrm{C}$. Untreated RNA samples and control RNA samples that were dialyzed and lyophilized without any modification were equally effective. Because the cutting molecular weight of the dialyzing membrane used was 1000 and thus nucleotides smaller than 4 bp were lost during the dialysis, actions of RNA appeared to be largely attributable to polynucleotides (molecular weight $>$ $1000)$.

Mechanisms of Action of RNA on In Vitro Ig Production by CBMNC. 1) Effects of time course of RNA supplementation to culture. RNA were added to the medium at $0,1,3,5$, and $7 \mathrm{~d}$ of the culture of CBMNC in the presence or absence of PWM $(1: 1000)$. The IgM levels in the supernatant at $\mathrm{d} 8$ of the culture were examined. The results of four experiments using four cord blood samples are summarized in Figure 2. Spontaneous and PWM-potentiated IgM production was augmented most when RNA was supplemented at $d 0$ of the culture. The enhancing action of RNA was significantly reduced when RNA was added to the culture at $\mathrm{d} 3$ or later.

2) Effects of RNA on proliferation of $T$ cells and other lineage' cells. Unseparated cells, T-cell-enriched cell suspensions, and Tcell-depleted cell suspensions prepared from CBMNC or PBMNC were incubated for $2 \mathrm{~d}$ in the presence of RNA $(0.1 \mathrm{~g} /$ L) or Con $A(1 \mu \mathrm{g} / \mathrm{mL})$, and their proliferative responses were studied by MTT assay as described in Materials and Methods. In four experiments, control Con $\mathrm{A}$ induced significant lymphocyte proliferation for PBMNC (S.I.: $8.3 \pm 2.0$ for T-enriched cells, $6.8 \pm 1.2$ for T-depleted cells, and $15.2 \pm 4.8$ for unseparated $\mathrm{PBMNC}$ ). Proliferative responses of $\mathrm{CBMNC}$ to Con $\mathrm{A}$ were significantly less compared with those of PBMNC (S.I. of CBMNC to Con A: $2.9 \pm 0.4$ for T-enriched cells, $1.5 \pm 0.2$ for T-depleted cells, and $3.9 \pm 0.6$ for unseparated CBMNC). In the presence of RNA. S.I. was less than 2 for all cell populations tested in both CBMNC and PBMNC. Thus, it may be concluded that the yeast RNA preparations used do not enhance significant proliferation of cord blood lymphocytes.

3) Effects of depletion of $T$ cells on actions of $R N A$. CD2 ${ }^{+} \mathrm{T}$ cells were depleted from CBMNC by E rosetting and IgM production by unseparated as well as T-depleted CBMNC was studied in the presence of medium only or RNA $(0.1 \mathrm{~g} / \mathrm{L})$. The results of four experiments were summarized in Table 3. Namely, the depletion of $\mathrm{CD}^{+} \mathrm{T}$ cells completely abolished the enhancing actions of polynucleotides on PWM-potentiated IgM production by CBMNC as observed in PBMNC (3). RNA still appeared to moderately enhance spontancous Ig production by T-depleted cells (Table 3). However, interestingly, this spontaneous IgM

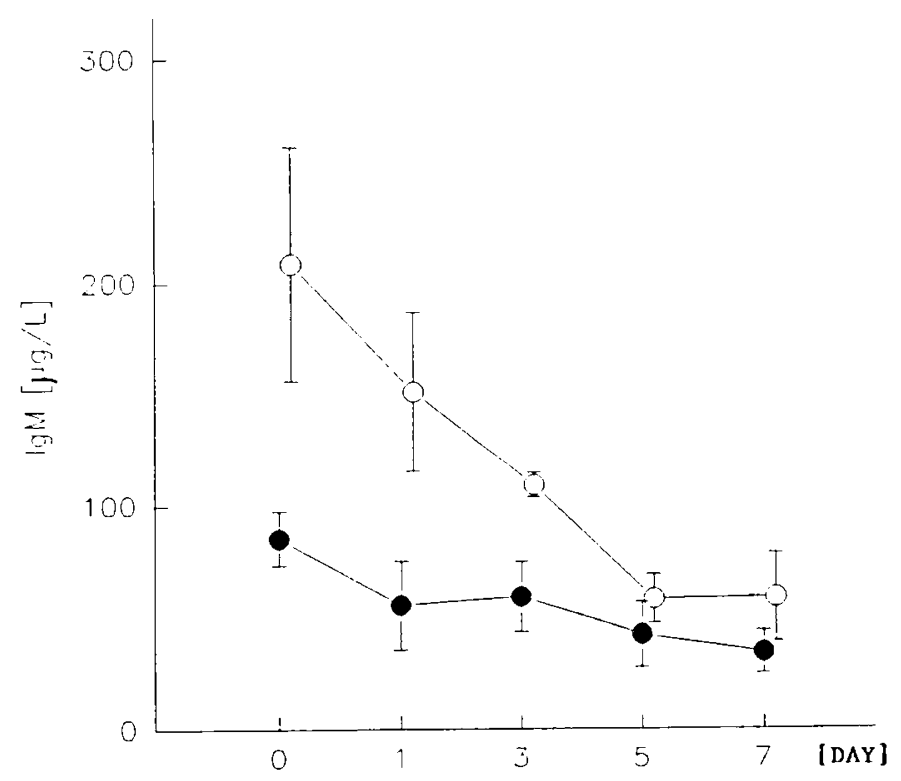

Fig. 2. Time course of the supplementation of RNA to the culture. Yeast RNA reparations $(0.1 \mathrm{~g} / \mathrm{L})$ were added to the culture at $\mathrm{d} 0,1,3$. 5 , and 7 of the culture when cells were incubated with medium alone (ब) or PWM (1:1000) (O). Each data point represents the mean value \pm SEM obtained in four experiments. In each experiment. CBMNC were obtained from a different individual. 
Table 3. Effects of depletion of T cells on Ig production by CBMNC and PBMNC*

\begin{tabular}{lccc}
\hline & \multicolumn{3}{c}{ IgM production $(\mu \mathrm{g} / \mathrm{L})$ by } \\
\cline { 2 - 4 } & $\begin{array}{c}\text { Unseparated } \\
\text { cells }\end{array}$ & $\begin{array}{c}\text { T-depleted } \\
\text { cells }\end{array}$ & $\begin{array}{c}\text { T-enriched cells }+ \\
\text { T-depleted cells }\end{array}$ \\
\hline PBMNC & & & \\
No additives & $705 \pm 221$ & $582 \pm 21.3$ & $417 \pm 31.1$ \\
RNA (0.1 g/L) & $990 \pm 245$ & $485 \pm 241$ & $767 \pm 63.5$ \\
PWM (1:1000) & $970 \pm 113$ & $190 \pm 94.7$ & $200 \pm 52.7$ \\
& & $(p<0.05) \dagger$ & $(p<0.05)$ \\
PWM + RNA & $1796 \pm 231$ & $227 \pm 118$ & $295 \pm 37.8$ \\
(0.1 g/L) & & $(p<0.05)$ & $(p<0.05)$ \\
CBMNC & & & \\
No additives & $56.5 \pm 5.6$ & $41.2 \pm 19.0$ & $29.8 \pm 11.1$ \\
RNA (0.1 g/L) & $129 \pm 13.8$ & $152 \pm 29.3$ & $208 \pm 16.6$ \\
& & & $(p<0.02)$ \\
PWM (1:1000) & $62.2 \pm 21.5$ & $43.7 \pm 14.3$ & $28.0 \pm 14.3$ \\
PWM + RNA & $228 \pm 53.2$ & $32.0 \pm 12.0$ & $55.7 \pm 23.0$ \\
(0.1 g/L) & & $(p<0.02)$ & $(p<0.05)$ \\
\hline
\end{tabular}

* IgM production was measured in both PBMNC and CBMNC by unseparated cells. T-depleted cells, and T-enriched cells plus T-depleted cells in a diffusion chamber, in the presence of additives. The results were expressed as mean IgM levels \pm SEM. These are the results of four experiments, and in each experiment one PBMNC sample and one CBMNC sample were used.

+ Significantly lower or higher compared with the values obtained when unseparated cells were used.

production by CBMNC appeared to be further augmented when T-depleted cells were cocultured with T-enriched cells in a diffusion chamber, which does not permit cognitive interactions between $T$ cells and non- $T$ lineage cells. IgG production by CBMNC was minimal irrespective of the presence of $T$ cells, although the depletion of $\mathrm{T}$ cells significantly reduced $\mathrm{IgG}$ production by adult PBMNC.

4) Effects of serum-free medium on actions of RNA. CBMNC were incubated in the presence of RNA in either a medium supplemented with $2 \%$ FCS or a serum-free medium supplemented with serum replacement product, as detailed in Materials and Methods, for $7 \mathrm{~d}$; IgM production by CBMNC in response to PWM $(1: 1000)$ and SAC $(0.005 \%)$ was examined. Polynucleotides enhanced IgM production by both PBMNC and CBMNC in response to PWM equally in a serum-free medium in a medium supplemented with FCS (Fig. 3 and data not shown). Responses to SAC were not significantly altered in the presence of polynucleotides irrespective of the medium used.

5) Effects of preincubation of unseparated. T-enriched, or $T$ depleted CBMNC with RNA before cullure. T-enriched cells and T-depleted cells were prepared from both adult PBMNC and CBMNC and incubated with RNA $(0.1 \mathrm{~g} / \mathrm{L})$ for $3 \mathrm{~h}$ along with control unseparated cells and then washed three times with PBS before the culture of Ig production. Then cells were incubated for $7 \mathrm{~d}$, and IgM production in the presence of PWM (1:1000), SAC $(0.005 \%)$, and RNA $(0.1 \mathrm{~g} / \mathrm{L})$ were examined. In each experiment, one adult PBMNC and one CBMNC sample were used. The results of six experiments were summarized in Table 4. Namely, the incubation of both CBMNC and PBMNC with RNA before the culture enhanced Ig production in response to all stimulants used. This nonspecific augmentation of IgM production by preincubation of cells with RNA was not observed when cells were depleted of $T$ cells. When T-enriched cells were preincubated with RNA separately before the coculture of Tdepleted cells, this enhancing action of RNA was equally observed for both PBMNC and CBMNC, although the responses of CBMNC were significantly less than those of PBMNC (Table 4). Alternatively, when T-depleted cells were preincubated with RNA and cocultured with T-enriched cells, no significant enhancement of IgM production was observed in two experiments
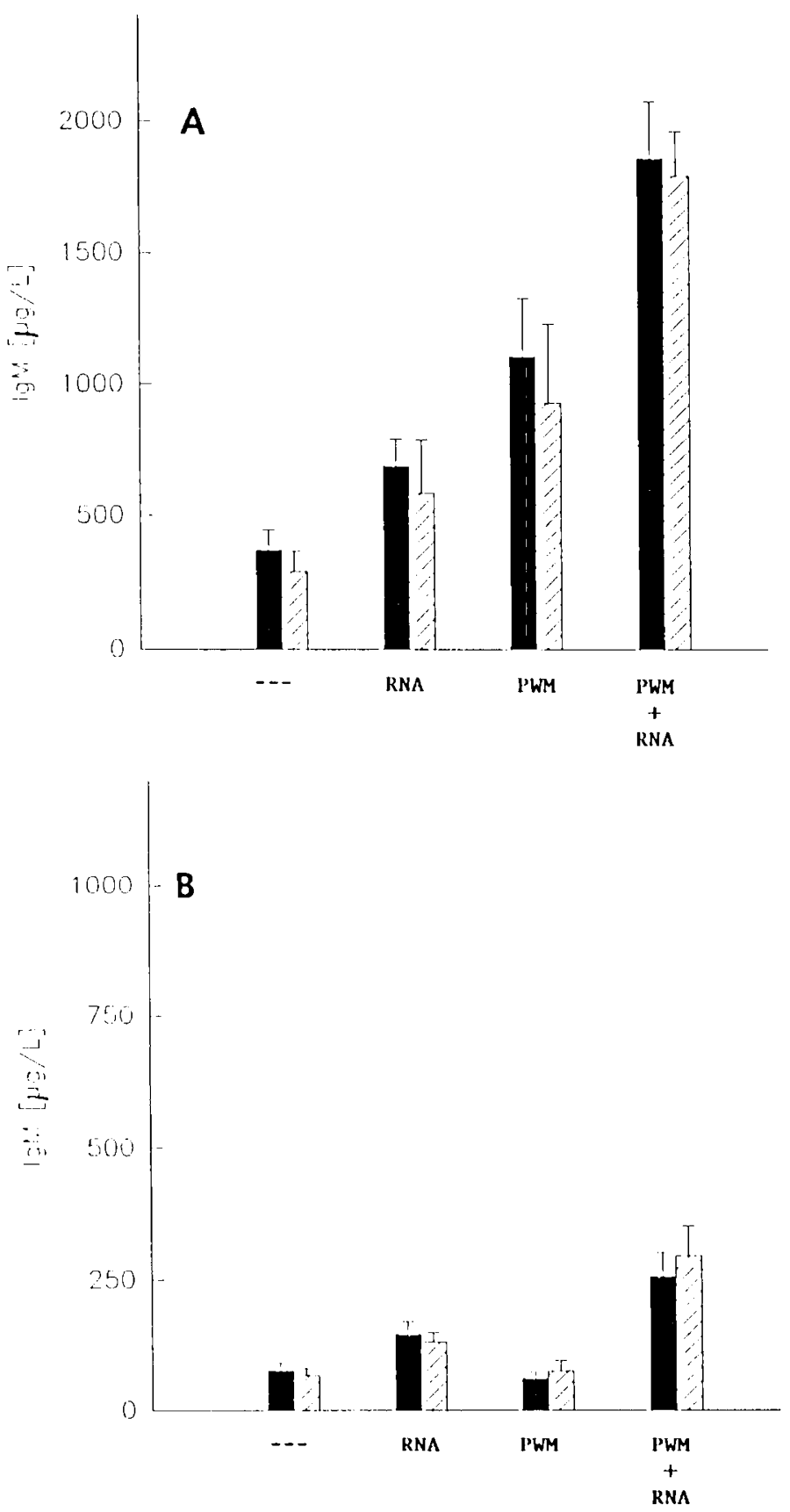

Fig. 3. CBMNC (A) and PBMNC $(B)$ were incubated in either a medium supplemented with $2 \%$ FCS $(\square)$ or a serum-free medium (D), and the effects of yeast RNA preparations on spontaneous or PWMpotentiated Ig production were examined. These are the results of five experiments.

(data not shown). Therefore, it may be concluded that polynucleotides can augment IgM production by both CBMNC and $\mathrm{PBMNC}$ through $\mathrm{T}$ lineage cells in the absence of $\mathrm{Ag}$ or nonspecific stimuli.

\section{DISCUSSION}

The objective of this study was to examine whether the nucleotides contained in breast milk contribute significantly to the maturation of the immune system in early infancy. Although breast milk has long been known to contain a significant amount of nucleotides (14), the nutritional importance of nucleotides is not well established or understood. Consequently, most infant formulas are not fortified with nucleotides. We and others have 
Table 4. Efffects of pre-incubation of CBMNC with RNA prior to the culture of Ig production*

\begin{tabular}{|c|c|c|c|}
\hline & \multicolumn{3}{|c|}{ IgM production $(\mu \mathrm{g} / \mathrm{L})$} \\
\hline & No stimulus & PWM $(1: 1000)$ & $\operatorname{SAC}(0.005 \%)$ \\
\hline \multicolumn{4}{|l|}{ PBMNC (adults) } \\
\hline Unseparated cells (no incubation with RNA) & $216 \pm 65.2$ & $748 \pm 135$ & $1144 \pm 143$ \\
\hline Unseparated cells (preincubated with RNA) & $461 \pm 200$ & $\begin{array}{l}11.38 \pm 84.9 \\
(p<0.05)\end{array}$ & $1434 \pm 99.2$ \\
\hline T-depleted cells (preincubated with RNA) & $292 \pm 60.5$ & $320 \pm 62.6$ & $952 \pm 158$ \\
\hline T-enriched cells (preincubated with RNA) $\dagger$ & $222 \pm 76.8$ & $\begin{array}{l}1190 \pm 191 \\
(p<0.1)\end{array}$ & $1390 \pm 184$ \\
\hline \multicolumn{4}{|l|}{ CBMNC } \\
\hline Unseparated cells (no incubation with RNA) & $29.9 \pm 12.3$ & $47.3 \pm 46.6$ & $400 \pm 30.1$ \\
\hline Unseparated cells (preincubated with RNA) & $102 \pm 30.7$ & $\begin{array}{c}192 \pm 23.2 \\
(p<0.001)\end{array}$ & $\begin{array}{l}617 \pm 104 \\
(p<0.05)\end{array}$ \\
\hline T-depleted cells (preincubated with RNA) & $12.4 \pm 4.1$ & $21.8 \pm 5.3$ & $249 \pm 46.5$ \\
\hline T-enriched cells (preincubated with RNA) & $58.2 \pm 31.3$ & $\begin{array}{l}131 \pm 27.2 \\
(p<0.05)\end{array}$ & $\begin{array}{l}487 \pm 45.4 \\
(p<0.05)\end{array}$ \\
\hline
\end{tabular}

* Unseparated. T-enriched, and T-depleted cells were preincubated with RNA $(0.1 \mathrm{~g} / \mathrm{L})$ for $3 \mathrm{~h}$, washed well, and tested for $\mathrm{Ig}$ production in response to PWM, SAC, and RNA. After a 7-d culture, the culture supernatant was tested for IgM levels by ELISA as detailed in Materials and Methods.

$\dagger$ T-enriched cells were preincubated with RNA $(0.1 \mathrm{~g} / \mathrm{L})$ for $3 \mathrm{~h}$, washed well, and cocultured with T-depleted cells. The ratio of T-enriched cells to T-depleted cells used in these experiments was $4: 1$. In two experiments. T-enriched cells incubated for $3 \mathrm{~h}$ without RNA did not significantly enhance IgM production in response to SAC or PWM.

shown the potentially significant immunomodulating actions of RNA in both animals and humans both in vivo and in vitro (1$3,15-19)$. Most of these studies were carried out by using mature lymphocytes. Because neonates are born with relatively immature immune systems and do not reach a mature state of immunity before 2 y of age (20), it may be difficult to assess the immunomodulating actions of nucleotides in breast milk based on the results obtained in mature lymphocytes. Cord blood $\mathrm{T}$ lymphocytes are phenotypically and functionally immature, lacking the features of memory $\mathrm{T}$ cells and providing poor helper functions to B cells (4-7). Cord blood B cells are also phenotypically distinct from mature peripheral blood $\mathrm{B}$ cells with increased expression of CD23 and CD5 $(21,22)$ and are probably functionally immature (7). Thus, in this study we attempted to study the actions of nucleotides on immature human lymphocytes by using CBMNC.

CBMNC from FT babies produced much less IgM or IgG in response to various stimuli, consistent with other reports (4-7). $\operatorname{IgA}$ production was minimal irrespective of the stimuli provided. However, RNA enhanced IgM production significantly in response to PWM and TNP-KLH. Unlike PBMNC, IgG production by CBMNC was not significantly altered in the presence of RNA. Spontaneous IgM production by CBMNC also appeared to be augmented in the presence of RNA. This enhancing action of RNA on IgM production by CBMNC was not appreciably demonstrated by the mononucleotide mixture and was significantly reduced when RNA was decomposed with alkali or modified pyrimidine bases or oxidized. RNA samples deprived of oligonucleotide (molecular weight $<1000$ ) did not lose their enhancing action on IgM production by CBMNC. In previous studies, we have shown that yeast RNA samples used in this study already degraded into $<1 \mathrm{kbp}$ when denatured with glyoxal, and their action was greatly reduced by RNAse treatment (1). Thus, it may be concluded that this enhancing action of RNA could be attributed to polypeptides (molecular weight $>1000$, corresponding to nucleotides larger than 4 bp but perhaps smaller than $1 \mathrm{kbp}$ ) as observed in PBMNC (3).

This assumption naturally raises the question of how polynucleotides exert their actions on CBMNC, because they may be rapidly degraded by abundant RNAse in the cell membranes. Optimal enhancement of $\mathrm{IgM} / \mathrm{IgG}$ production by adult PBMNC was obtained when both T cells and RNA were present during the initial stage of the culture of Ig production (3). The previous data obtained in mice suggest that polynucleotides augment specific $\mathrm{Ab}$ responses to $\mathrm{TD}-\mathrm{Ag}$ partly through modulating the cognitive cell-cell interactions between $\mathrm{T}$ cells and Ag-presenting cells in the initial stage of $\mathrm{Ag}$ presentation (23). In this study, we have also observed that the enhancing action of polynucleotides on IgM production by CBMNC was dose dependent and most effective when supplemented at the initial period of the culture. Previously, we found that polynucleotides are moderately mitogenic to murine spleen lymphocytes but not to immature lymphocytes (thymocytes) (1). In this study, we observed that yeast RNA preparations were only marginally mitogenic to both $T$ and non-T cells in both PBMNC and CBMNC. We also found that polynucleotides were equally effective in serum-free culture conditions, indicating that extracellular adherent molecules including fibronectin and vitronectin are not actively involved in this enhancing action of nucleotides. We postulate that polynucleotides exert their actions on various cell surface molecules of lymphocytes and other lineage cells before being degraded to modulate humoral immune responses. Such actions of polynucleotides could be observed locally in the site of inflammation and consequent cell destruction.

We also demonstrated that the depletion of $T$ cells abolished the enhanced actions of RNA on IgM production to TD-Ag in CBMNC as observed in adult PBMNC (3). The depletion of $\mathrm{T}$ cells did not suppress augmented spontancous IgM production by RNA in CBMNC. The preincubation of cells with polynucleotides for a short period before the culture was sufficient to enhance spontaneous or potentiated IgM production in both CBMNC and PBMNC. This nonspecific activation of Ig production in response to $\mathrm{T}$-dependent as well as $\mathrm{T}$-independent stimuli still seemed to be largely dependent on the presence of $\mathrm{T}$ cells.

In light of these contradictory results, we speculate that there are two different immunomodulating actions of polynucleotides. One is the nonspecific activation of $T$ cells and perhaps other lineage cells as well. The other is the more specific actions on Thelper cells and Ag-presenting cells at the stage of $\mathrm{Ag}$ presentation. Comparing the different responses of PBMNC and CBMNC, the enhancing actions of polynucleotides on specific $\mathrm{Ag}$ responses may be relatively weak in CBMNC, reflecting the presence of functionally immature $T$ helper lymphocytes.

$\mathrm{CBMNC}$ are abundant in $\mathrm{CD}^{+} \mathrm{Bl}$ cells. This minor $\mathrm{B}$ cell 
subset is thought to produce low-affinity polyclonal $\operatorname{IgM}$ antibodies, which are often cross-reactive to various pathogens encountered in the gastrointestinal tract and thus are postulated to function in the first-line, primitive immune defense system (24). Enhanced spontaneous IgM production by CBMNC in the presence of RNA may be attributed to the activation of $\mathrm{B} 1$ cells by polynucleotides. This may be beneficial for newborns who are exposed to various environmental pathogens for the first time, providing more protection by natural antibodies in addition to the maternally derived passive antibodies. However, B1 cells appear to contain self-reactive B cell clones, which may be negatively regulated by yet unknown mechanisms perhaps involving Ag stimuli and T helper cells (22).

It was also observed in this study that the absence of cell-cell interactions between $\mathrm{T}$ and $\mathrm{B}$ cells in CBMNC may further augment Ig production in the presence of polynucleotides, and the brief incubation of T-enriched cells with RNA $(3 \mathrm{~h})$ before the culture nonspecifically enhanced IgM production by CBMNC in response to both $\mathrm{T}$-dependent and $\mathrm{T}$-independent stimuli. However, when cell-cell interactions are permitted, only Ig production in response to T-dependent stimuli appeared to be augmented in the presence of polynucleotides. These results may indicate that during the period of cognitive cell-cell interactions between $T$ and other lineage cells, excessive nonspecific activation of both T and B cells was suppressed. Polynucleotides may augment this suppressive action further, perhaps through $\mathrm{T}$ lineage cells.

In summary, results obtained in this study demonstrated that polynucleotides exert significant immunomodulating actions on both $\mathrm{T}$ and non-T lineage cells in CBMNC, but their enhancing actions on Ig production may be limited to $\operatorname{lgM}$ in immature human lymphocytes. We have observed a profound decrease of humoral immune responses to TD-Ag in animals fed a nucleotide-free diet: these decreased responses were easily restored by supplementation with RNA or a mononucleotide/nucleoside mixture (25). The mononucleotide/nucleoside mixture did not enhance in vitro $\mathrm{Ab}$ production either (unpublished observations). Thus, it may be postulated that exogenous mononucleotides and nucleosides are incorporated into the tissue nucleotide pool relatively rapidly when the body's requirement surpasses $d e$ novo synthesis of nucleotides, consequently the immunomodulating actions of polynucleotides would be restored. This could very likely occur in early infancy when the body is in rapid growth. In this regard, exogenous nucleotides may have potential importance during early infancy, which should be taken into consideration when feeding nutritionally deprived infants.

Acknowledgments. The authors thank Drs. Eric L. Lien and G. Minnervini for their helpful reviews and Holly Reed for preparing the manuscript. We also thank the staff of Station 59. University of Minnesota Hospital and Clinic, for helping us collect cord blood samples.

\section{REFERENCES}

1. Jyonouchi H, Hill RJ, Good RA 1992 RNA/nucleotide enhances antibody production in vitro and is moderately mitogenic to murine spleen lymphocytes. Proc Soc Exp Biol Med 200:101-108
2. Jyonouchi H, Hill RJ, Voss RM, Ishii E 1993 Immunomodulating actions of RNA and nucleotides on murine lymphocytes in vitro. Augmentation of antibody production to $\mathrm{T}$-dependent antigens and expansion of $\mathrm{T}$ helper cells. J Nutr Immunol (in press)

3. Jyonouchi H. Zhang L. Tomita Y' 1993 Studies of immunomodulating actions of RNA/nucleotides. RNA/nucleotides enhance in vitro lg production by human peripheral blood mononuclear cells in response to $\mathrm{T}$-dependent stimuli. Pediatr Res 33:458-465

4. Pisetsky DS, Jelinek DF, McAnally LM. Reich CF Lipsky PE 1990 In vitro autoantibody production by normal adult and cord blood B cells. J Clin Invest 85:899-903

5. Watson W, Oen K. Ramdahin R, Harman C 1991 Immunoglobulin and cytokine production by neonatal lymphocytes. Clin Exp Immunol 83:169174

6. Israel H, Odziemiec C. Ballow M 1991. The effects of retinoic acid on immunoglobulin synthesis by human cord blood mononuclear cells. Clin Immunol Immunopathol 59:417-425

7. Splawski JB, Jelinek DF, Lipsky PE 1991 Delineation of the functional capacity of human neonatal lymphocytes. J Clin Invest 87:545-553

8. Cambier JC, Monroe JG, Neale MJ 1982 Definition of conditions which facilitate antigen specific activation of the majority of isolated trinitrophenol binding B cells. J Exp Med 156:1635-1649

9. Small TN, Keever CA, Weiner-Fedus S. Heller G. O'Reilly RJ, Flomenherg N 1990 B-cell differentiation following autologous. conventional, or T-cell depleted bone marrow transplantation: a recapitulation of normal B-cell ontogeny. Blood 76:1647-1656

10. Mosmann TR 1983 Rapid calorimetric assay for cellular growth and survival: application to proliferation and cytotoxicity assay. J Immunol Methods 65:55-63

11. Schuster II 1961 The reaction of tobacco mosaic virus ribonucleic acid with hydroxylamine. J Mol Biol 3:447-457

12. Bock RM 1967 Controlled partial hydrolysis of RNA. In: Colowick SP. Kaplan NO (eds) Methods on Enzymology, Vol 12. Academic Press, New York, pp $218-221$

13. Hayatsu H, Ukita T 1967 The selective degradation of pyrimidines in nucleic acids by premanganate oxidation. Biochem Biophy Res Commun 29:561556

14. Uauy R 1989 Dietary nucleotide and requirements in early life. In: E Leventhal (ed). Textbook of Gastroenterology and Nutrition in Infancy, 2nd Ed. Raven Press, New York, pp 265-280

15. Rudolph FB, Kulkarni AD, Fanslow WE, Pizzini RP, Kumar S, Van Buren CT 1990 Role of RNA as a dietary source of pyrimidines and purines in immune function. Nutrition $6: 45-52$

16. Kulkarni AD. Fanslow WC. Rudolph FB. Van Buren CT 1988 Modulation of delayed hypersensitivity in mice by dietary nucleotide restriction. Transplantation $44: 847-849$

17. Van Buren CT, Kulkarni AD, Fanslow WC, Rudolph FB 1985 Dietary nucleotide, a requirement for helper/inducer $T$ lymphocytes. Transplantation 40:694-697

18. Kulkarni AD. Fanslow WC, Rudolph FB, Van Buren CT 1986 Effect of dietary nucleotide on response to bacterial infections. J Parenter Enteral Nutr 10:169-171

19. Fanslow WC, Kulkarni AD, Van Buren CT, Rudolph FB 1988 Effect of nucleotide restriction and supplementation on resistance to experimental murine candidiasis. J Parenter Enteral Nutr 12:49-52

20. Miyawaki T. Noriya N. Nagaoki T. Taniguchi N 1981 Maturation of B cell differentiation ability and T-cell regulatory function in infancy and childhood. Immunol Rev 57:61-87

21. Kim K-M. Tanaka M. Iwai Y', Ito S. Mayumi M. Shinomiya K. Mikawa H $1988 \mathrm{JgE}$ receptor-bearing lymphocytes in allergic and nonallergic children. Pediatr Res 24:254-257

22. Kasaian MT. Ikematsu H, and Casali P 1991 CD5 $^{+}$B lymphocytes. Proc Soc Exp Biol Med 197:226-241

23. Jyonouchi H, Zhang L. Tomita Y 1993 RNA/nucleotides enhance in vitro antibody and immunoglobulin production to $\mathrm{T}$-dependent antigen but do not facilitate polyclonal $B$ cell activation in both normal and an autoimmune-prone NZB strain of mice. J Nutr Immunol (in press)

24. Rajewsky K 1992 Early and Late B-cell development in the mouse. Curr Opin Immunol 4:171-176

25. Zhang L, Jyonouchi II, Yokoyama H, Tomita Y 1993 Immunomodulating actions of nucleotides on $\mathrm{Ab} / \mathrm{lg}$ production by murine spleen lymphocytes in vive and in vitro. FASEB J 7:A3012(abstr) 